\title{
UPAYA MENINGKATKAN HASIL BELAJAR MATEMATIKA PADA \\ MATERI SIFAT-SIFAT BANGUN RUANG SEDERHANA MELALUI PENERAPAN METODE PROBLEM SOLVING SISWA KELAS VI B SD NEGERI PAJAMBON
}

\author{
Herlina \\ SD Negeri Pajambon, Kabupaten Kuningan \\ Pengutipan: Herlina. (2019). Upaya meningkatkan hasil belajar matematika pada materi sifat- \\ sifat bangun ruang sederhana melalui penerapan metode problem \\ solving siswa Kelas VI B SD Negeri Pajambon. Pedagogi: Jurnal \\ Penelitian Pendidikan, 6 (1), hlm 25-31.
}

Diajukan: 03-05-2019Ｄiterima: 30-05-2019Ｄiterbitkan: 31-05-2019

\begin{abstract}
ABSTRAK
Tujuan dari penelitian ini adalah untuk mengetahui peningkatan hasil belajar mata pelajaran Matematika pada materi sifat-sifat bangun ruang sederhana siswa kelas VI B SD Negeri Pajambon melalui penerapan metode pemecahan masalah (problem solving). Metode penelitian ini adalah penelitian tindakan kelas. Penelitian dilaksanakan dalam 2 siklus perbaikan, dan masing-masing siklus 2 pertemuan. Subjek penelitian ini adalah siswa kelas VI B SD Negeri Pajambon Kabupaten Kuningan pada mata pelajaran Matematika. Jumlah siswa sebanyak 22 orang, terdiri dari 11 laki-laki dan 11 perempuan. Teknik pengumpulan data dalam penelitian ini dilakukan melalui kegiatan berupa: (1) perencanaan tindakan; (2) pelaksanaan tindakan; (3) pengamatan tindakan; dan (4) refleksi Hasil penelitian menunjukan adanya peningkatan rata-rata kelas sebesar 54,76 pada pertemuan 1 Siklus I, menjadi 66,19 pada pertemuan 2 Siklus I, menjadi 73,8 pada pertemuan 1 Siklus II dan menjadi 83,33 pada pertemuan 2 siklus II. Sementara dari persentase ketuntasan terjadi peningkatan dari 9,52\% pada pertemuan 1 Siklus I, menjadi $19,04 \%$ pada pertemuan 2 Siklus 1, menjadi 33,33\% pada pertemuan 1 Siklus II dan menjadi $85,71 \%$ pada pertemuan 2 Siklus II. Dari hasil tersebut maka dapat dillihat bahwa nilai dan persentase ketuntasan selalu mengalami kenaikan pada setiap siklusnya, baik pertemuan 1 maupun pertemuan 2. Sehingga dapat disimpulkan bahwa penerapan metode pemecahan masalah (problem solving) dapat meningkatkan hasil belajar mata pelajaran Matematika pada materi sifat-sifat bangun ruang sederhana siswa kelas VI B SD Negeri Pajambon.
\end{abstract}

Kata kunci: Hasil Belajar, Metode Pemecahan Masalah (Problem Solving), Matematika 


\section{Herlina}

Upaya Meningkatkan Hasil Belajar Matematika pada Materi Sifat-Sifat Bangun Ruang

Sederhana melalui Penerapan Metode Problem Solving Siswa Kelas VI B SD Negeri

Pajambon

\section{PENDAHULUAN}

Pada hakikatnya kegiatan belajar-mengajar adalah suatu proses interaksi atau hubungan timbal balik antara guru dan siswa dalam satuan pembelajaran. Guru sebagai salah satu komponen dalam proses belajar mengajar merupakan pemegang peran yang sangat penting. Guru bukan hanya sekedar penyampai materi saja, tetapi lebih dari itu, guru dapat dikatakan sebagai sentral pembelajaran. Sebagai pengelola sekaligus pelaku dalam proses belajarmengajar, guru-lah yang mengarahkan bagaimana proses belajar-mengajar itu dilaksanakan. Oleh karena itu, guru harus dapat membuat suatu pengajaran menjadi lebih efektif juga menarik sehingga bahan pelajaran yang disampaikan akan membuat siswa merasa senang dan merasa perlu untuk mempelajari bahan pelajaran tersebut.

Berhasilnya tujuan pembelajaran ditentukan oleh banyak faktor, diantaranya adalah faktor guru dalam melaksanakan proses belajar-mengajar. Hal tersebut dikarenakan guru secara langsung dapat mempengaruhi, membina, dan meningkatkan kecerdasan serta keteampilan siswa. Untuk mengatasi permasalahan dan guna mencapai tujuan pendidikan secara maksimal, peran guru sangat penting. Harapannya, guru mampu memilih metode pembelajaran yang tepat dan sesuai dengan konsep-konsep mata pelajaran yang akan disampaikan.

Metode pembelajaran jenisnya beragam yang masing-masing memiliki kelebihan dan kelemahan. Maka dari itu, pemilihan metode yang sesuai dengan topik atau pokok bahasan yang akan diajarkan harus betul-betul dipikirkan oleh guru yang akan menyampaikan materi pembelajaran. Pemilihan metode mengajar hedaknya disesuaikan dengan kebutuhan. Dalam proses pemilihannya, dalam setiap kali pertemuan kelas bukanlah asal pakai, tetapi setelah melalui seleksi kebutuhan oleh guru. Pemakaian metode yang satu digunakan untuk mencapai tujuan yang satu, sementara penggunaan metode yang lain juga digunakan untuk mencapai tujuan yang lain.

Pemilihan metode pembelajaran harus dilaksanakan sesuai dengan kriteria, sebagaimana dikemukakan oleh Sudjana (2008: 90) bahwa "Penentuan metode harus mempertimbangkan faktor-faktor lain. Sebagai suatu cara, metode tidaklah berdiri sendiri, tetapi dipengaruhi oleh faktor-faktor lain. Maka dari itu, siapapun yang telah menjadi guru harus mengenal, memahaminya, dan mempedomaninya ketika akan melaksanakan pemilihan dan penentuan metode. Tanpa mengindahkan hal ini, metode yang dipergunakannya bisa-bisa tiada arti. Dengan demikian, maka pemilihan metode yang tepat hendaknya mempertimbangkan banyak faktor di antaranya tujuan, siswa, fasilitas, dan sebagainya.

Matematika menurut Departemen Pendidikan dan Kebudayaan (2003: 6) merupakan suatu bahan kajian yang memiliki objek abstrak dan dibangun melalui proses penalaran deduktif, yaitu kebenaran suatu konsep diperoleh sebagai akibat logis dari kebenaran sebelumnya sehingga berkaitan antar konsep dalam matematika bersifat sangat kuat dan jelas. Dalam pembelajaran matematika, agar mudah dimengerti siswa, proses penalaran induktif dapat dilakukan pada awal pembelajaran dan kemudian dilanjutkan dengan proses penalaran deduktif untuk menguatkan pemahaman yang sudah dimiliki siswa.

Pengajaran menurut Rohani (2004: 4) merupakan perpaduan dari dua aktivitas, yaitu aktivitas mengajar dan aktivitas belajar. Pengajaran matematika akan bisa disebut berjalan dan berhasil dengan baik, manakala ia mampu mengubah diri peserta didik selama ia terlibat di dalam proses pengajaran itu dan dapat dirasakan manfaatnya secara langsung.

Perkembangan ilmu pengetahuan dan teknologi memungkinkan semua pihak dapat memperoleh informasi dengan melimpah, cepat, dan mudah dari berbagai sumber dan tempat di dunia. Selain perkembangan yang pesat, perubahan juga terjadi dengan cepat. Oleh karenanya, diperlukan kemampuan untuk memperoleh, mengelola, dan memanfaatkan informasi untuk bertahan pada keadaan yang selalu berubah, tidak pasti, dan kompetitif. Kemampuan ini membutuhkan pemikiran, antara lain berpikir sistematis, logis, dan kritis yang 
dapat dikembangkan melalui pembelajaran metematika. Agar siswa dapat berpikir secara sistematis, logis, dan berpikir abstrak dalam menggunakan pemecahan masalah matematika serta melakukan komunikasi dengan menggunakan simbol, tabel, grafik, dan diagram yang dikembangkan melalui pembelajaran yang dilakukan secara bertahap dan berkesinambungan.

Pembelajaran matematika memerlukan media yang sesuai. Menurut Mulyasa (2005: 47) suatu faktor yang menyebabkan rendahnya kualitas pembelajaran antara lain belum dimanfaatkannya sumber belajar secara maksimal, baik oleh guru maupun oleh peserta didik. Sejalan dengan itu, Djamarah (2002: 13) juga menyatakan bahwa bahan ajar merupakan wahana penyalur informasi belajar.

Menurut Suharta (2001: 1) dalam pembelajaran matematika selama ini, dunia nyata hanya dijadikan tempat mengaplikasikan konsep. Siswa mengalami kesulitan belajar matematika di kelas. Akibatnya, siswa kurang menghayati atau memahami konsep-konsep matematika, dan siswa mengalami kesulitan untuk mengaplikasikan matematika dalam kehidupan sehari-hari.

Hasil belajar pada dasarnya adalah suatu kemampuan yang berupa keterampilan dan perilaku baru sebagai akibat latihan atau pengalaman. Dalam hal ini, Soerdijarto (1993) mendefinisikan hasil belajar sebagai tingkat penguasaan suatu pengetahuan yang dicapai oleh siswa dalam mengikuti program belajar-mengajar sesuai dengan tujuan pendidikan yang ditetapkan. Sedangkan Gagne dan Briggs (1992) menyatakan bahwa hasil belajar adalah kemampuan yang diperoleh seseorang sesudah mengikuti proses belajar. Selain itu, Bloom (1979) membagi hasil belajar ke dalam tiga ranah yaitu kognitif, afektif, dan psikomotor. Ranah kognitif berkaitan dengan tujuan-tujuan pembelajaran yang berkaitan dengan kemampuan berpikir, mengetahui dan memecahkan masalah. Ranah afektif berkaitan dengan tujuan-tujuan yang berhubungan dengan perasaan, emosi, nilai, dan sikap yang menunjukkan penerimaan atau penolakan terhadap sesuatu. Ranah psikomotor berkaitan dengan keterampilan motorik, manipulasi bahan atau objek.

Pengertian hasil belajar dalam penelitian ini hanya dibatasi pada definisinya sebagai angka yang diperoleh siswa yang telah berhasil menuntaskan konsep-konsep mata pelajaran sesuai dengan kriteria ketuntasan minimal (KKM) yang ditetapkan sesuai dengan kurikulum yang berlaku. Prinsip yang mendasari penilaian hasil belajar yaitu untuk memberi harapan bagi siswa dan guru untuk dapat meningkatkan kualitas pembelajaran. Kualitas dalam arti siswa menjadi pembelajar yang efektif dan guru menjadi motivator yang baik. Dalam kaitan dengan itu, guru dan pembelajar dapat menjadikan informasi hasil penilaian sebagai dasar dalam menentukan langkah-langkah pemecahan masalah, sehingga mereka dapat memperbaiki dan meningkatkan belajarnya (Rasyid, 2008: 67).

Berdasarkan pengalaman penulis, hasil refleksi diri penulis menemukan bahwa dalam mencapai tujuan pembelajaran pada mata pelajaran Matematika di sekolah dasar, khususnya di SD N Pajambon, Kabupaten Kuningan masih banyak mengalami kesuliatan, baik dalam penyampaian materi maupun pemilihan metode yang digunakan untuk penyampaian materi itu sendiri. Hal ini terlihat dari masih rendahnya nilai mata pelajaran Matematika. Nilai rata-rata kelas pada materi pokok ini yaitu 58,1. Padahal pembelajaran harus memenuhi KKM 70. Bertitik tolak dari hal tersebut di atas, perlu pemikiran-pemikiran dan tindakan-tindakan yang harus dilakukan agar siswa dalam mempelajari konsep-konsep Matematika tidak mengalami kesulitan. Oleh sebab itu, penggunaan pendekatan yang tepat dirasa sangat penting untuk membantu siswa dalam memahami konsep-konsep pembelajaran Matematika.

Demi mengatasi masalah tersebut, penulis bermaksud menggunakan metode pemecahan masalah (Problem Solving) yang mana sangat cocok diterapkan dalam mata pelajaran Matematika. Oleh karena, pendekatan ini memposisikan siswa sebagai produsen, bukan sebagai sekedar menerima ilmu pengetahuan. Metode pemecahan masalah akan menempatkan siswa sebagai ilmuwan karena siswa akan dibawa untuk bekerja sebagaimana 


\section{Herlina}

Upaya Meningkatkan Hasil Belajar Matematika pada Materi Sifat-Sifat Bangun Ruang

Sederhana melalui Penerapan Metode Problem Solving Siswa Kelas VI B SD Negeri

Pajambon

ilmuwan menemukan ilmu pengetahuan. Selain itu, metode pemecahan masalah (Problem Solving) merupakan suatu metode yang menggambarkan pengalaman atau masalah seseorang yang disusun untuk memancing perhatian atau perasaan para peserta latihan. Pemecahan masalah (Problem Solving) dapat dipergunakan untuk menggerakkan diskusi, meningkatkan kemampuan peserta latihan dalam menganalisis, menilai, dan memecahkan masalah yang dihadapi dalam dunia kehidupannya. Pemecahan masalah kritis dapat dipergunakan pula sebagai aktivitas belajar perorangan, kelompok atau kombinasi antara keduanya, karena: "Proses pembelajaran dengan pemecahan masalah melibatkan fisik, sosial, dan/atau intelektual dalam ranah psikomotorik yang akan mengantar siswa pada suatu pegetahuan/pemahaman dalam ranah kognitif serta menumbuhkan sikap dan nilai yang relevan (ranah afektif). Seluruh irama gerak atau tindakan dalam proses belajar mengajar seperti ini akan menciptakan kondisi cara belajar siswa aktif. Hal inilah yang dimaksud dalam pendekatan proses" (Conny Semiawan, dkk, 1985: 18).

Menurut Hamalik (1999: 151) metode pemecahan masalah adalah suatu metode mengajar dengan cara siswa dihadapkan pada suatu masalah yang harus dipecahkannya berdasarkan data atau informasi yang akurat sehingga mendapatkan suatu kesimpulan. Sedangkan menurut Polya dalam Karso (1994: 60) masalah dalam matematika bagi siswa adalah persoalan atau soal matematika. Selain memberikan masalah-masalah yang menantang selama di kelas, seorang guru matematika dapat saja memulai proses pembelajarannya dengan mengajukan masalah yang cukup menantang dan menarik bagi siswa. Siswa dan guru lalu bersama-sama memecahkan masalahnya tadi sambil membahas teori-teori, definisi-definisi maupun rumus-rumus matematika. Jadi, dengan menggunakan metode ini guru tidak memberikan informasi dulu, tetapi informasi diperoleh siswa setelah memecahkan masalah. Menurut Polya ada 4 langkah pemecahan masalah, yaitu: (1) Memahami masalah, yaitu memberikan bimbingan kepada siswa agar siswa tersebut dapat menentukan apa yang diketahui dalam soal tersebut dan menentukan apa yang ditanyakan. Namun jika siswa mengalami kegagalan, maka guru dapat memberikan bimbingan dengan cara diminta mengubah soal tersebut dengan kalimat sendiri. Selanjutnya, siswa diminta menulis apa yang diketahui dan apa yang ditanyakan; (2) Menyusun rencana pemecahan, yaitu mencari hubungan antara data yang diketahui atau yang belum diketahui Hal ini dapat dilakukan jika siswa mengerjakan langkah pertama dengan benar. Hubungan yang diperoleh sesuai dengan rencana penelitian ini adalah satu atau dua cara yang perlu disederhanakan; (3) Melaksanakan rencana pemecahan masalah; (4) Memeriksa kembali hasil yang telah diperoleh dengan soal aslinya.

Metode pemecahan masalah (Problem Solving) itu akan mengembangkan kreativitas siswa, yang mana pada gilirannya akan menjadi landasan untuk mengembangkan kepribadian secara keseluruhan. Penggunaan metode pemecahan masalah diharapkan dapat meningkatkan aktivitas siswa dalam proses belajar-mengajar sehingga dalam proses belajar mengajar itu aktivitasnya tidak hanya didominasi oleh guru. Dengan demikian, siswa akan terlibat secara fisik, emosional, intelektual yang mana pada gilirannya diharapkan konsep matematika yang diajarkan oleh guru dapat dipahami oleh siswa.

\section{METODE PENELITIAN}

Metode penelitian ini adalah penelitian tindakan kelas. Penelitian dilaksanakan dalam 2 siklus perbaikan, dan masing-masing siklus 2 pertemuan. Subjek penelitian ini adalah siswa kelas VI B SD Negeri Pajambon Kabupaten Kuningan pada mata pelajaran Matematika. Jumlah siswa sebanyak 22 orang, terdiri dari 11 laki-laki dan 11 perempuan. Teknik pengumpulan data dalam penelitian ini dilakukan melalui kegiatan berupa: (1) perencanaan tindakan; (2) pelaksanaan tindakan; (3) pengamatan tindakan; dan (4) refleksi. 


\section{HASIL PENELITIAN DAN PEMBAHASAN}

Setelah dilakukan proses perbaikan pembelajaran secara keseluruhan, maka peningkatan nilai evaluasi, rata-rata kelas pada proses perbaikan pembelajaran siklus I dan siklus II tertera pada tabel dan grafik rekapitulasi data hasil evaluasi perbaikan siklus I dan siklus II. Berdasarkan tabel tersebut dapat dilihat peningkatan nilai tertinggi, nilai terendah, nilai rata-rata hasil belajar, dan persentase ketuntasan. Rata-rata hasil belajar meningkat dari 54,76 pada pertemuan 1 Siklus I, menjadi 66,19 pada pertemuan 2 Siklus I, menjadi 73,8 pada pertemuan 1 Siklus II dan menjadi 83,33 pada pertemuan 2 siklus II.

Tabel 1. Rekapitulasi Data Hasil Perbaikan Siklus I dan II

\begin{tabular}{clcccc}
\hline \multirow{2}{*}{ No } & \multirow{2}{*}{ Kriteria } & \multicolumn{2}{c}{ Siklus I } & \multicolumn{2}{c}{ Siklus II } \\
\cline { 3 - 5 } & & Pert.1 & Pert.2 & Pert.1 & Pert.2 \\
\hline $\mathbf{1}$ & Nilai Tertinggi & 80 & 80 & 90 & 100 \\
\hline $\mathbf{2}$ & Nilai Terendah & 40 & 50 & 60 & 70 \\
\hline $\mathbf{3}$ & Rata-rata & 54,76 & 66,19 & 73,8 & 83,33 \\
\hline $\mathbf{4}$ & Prosentase Ketuntasan & $9,52 \%$ & $19,04 \%$ & $33,33 \%$ & $85,71 \%$ \\
\hline
\end{tabular}

Berdasarkan data tersebut, walaupun telah terjadi peningkatan pada rata-rata kelas dari siklus I pertemuan 1 ke pertemuan 2 namun penelitian dinyatakan baru dinyatakan berhasil pada siklus II. Sementara dari persentase ketuntasan terjadi peningkatan dari $9,52 \%$ pada pertemuan 1 Siklus I, menjadi $19,04 \%$ pada pertemuan 2 Siklus 1, menjadi 33,33\% pada petemuan 1 Siklus II dan menjadi $85,71 \%$ pada pertemuan 2 . Dengan demikian, berdasarakan persentase ketuntasan penelitian baru dinyatakan berhasil pada pertemuan 2 siklus II. Peningkatan hasil belajar pada setiap pertemuan pada siklus I dan Siklus II, lebih jelas disajikan sebagai berikut.

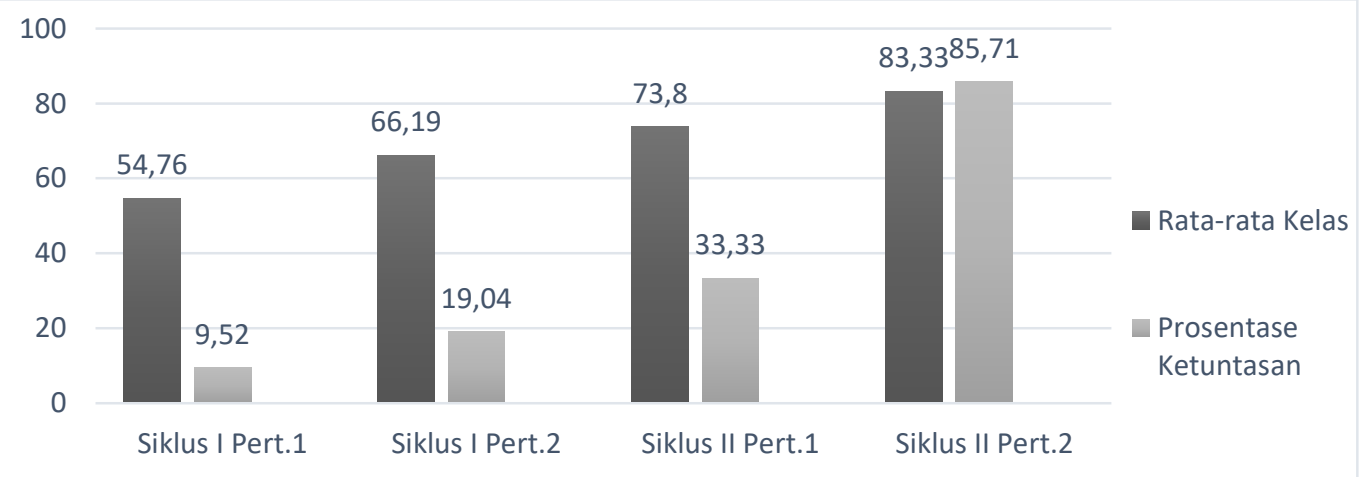

Gambar 1. Rekapitulasi Data Hasil Perbaikan Siklus I dan II

Berdasarkan pembahasan setiap siklus, maka secara keseluruhan telah terjadi peningkatan hasil belajar dari silklus 1 pertemuan 1 baik pada nilai rata-rata kelas maupun persentase ketuntasan. Penelitian mencapai kriteria keberhasilan saat baik nilai rata-rata kelas maupun persentase ketuntasan mencapai kriteria keberhasilan, 70 dan $80 \%$, yaitu pada siklus II pertemuan 2 sebesar 83,33 untuk rata-rata kelas dan 85,71\% untuk persentase penilaian.

Proses perbaikan pembelajaran yang dilakukan pada siklus I, metode pemecahan masalah (problem solving) yang digunakan kurang efektif dan hanya terpusat pada siswa yang pintar saja. Sedangkan pada siklus II penggunaan metode pemecahan masalah (problem solving) dan intensitas bimbingan guru terhadap siswa yang kurang paham ditingkatkan, sehingga siswa dapat memahami proses melalui masukan dari teman dan guru. 


\section{Herlina}

Upaya Meningkatkan Hasil Belajar Matematika pada Materi Sifat-Sifat Bangun Ruang

Sederhana melalui Penerapan Metode Problem Solving Siswa Kelas VI B SD Negeri

Pajambon

\section{SIMPULAN DAN SARAN}

Berdasarkan hasil penelitian, dapat disimpulkan bahwa penerapan metode pemecahan masalah (problem solving) dapat meningkatkan hasil belajar mata pelajaran Matematika pada materi sifat-sifat bangun ruang sederhana siswa kelas VI B SD Negeri Pajambon. Hal ini dapat dilihat dari rata-rata hasil belajar meningkat dari 54,76 pada pertemuan 1 Siklus I, menjadi 66,19 pada pertemuan 2 Siklus I, menjadi 73,8 pada pertemuan 1 Siklus II dan menjadi 83,33 pada pertemuan 2 siklus II. Sementara dari persentase ketuntasan, terjadi peningkatan dari 9,52\% pada pertemuan 1 Siklus I, menjadi $19,04 \%$ pada pertemuan 2 Siklus 1, menjadi 33,33\% pada petemuan 1 Siklus II dan menjadi $85,71 \%$ pada pertemuan 2. Berdasarkan pembahasan setiap siklus, maka secara keseluruhan telah terjadi peningkatan hasil belajar dari silklus 1 pertemuan 1 baik pada nilai rata-rata kelas maupun persentase ketuntasan, dimana penelitian mencapai kriteria keberhasilan saat baik nilai rata-rata kelas maupun persentase ketuntasan mencapai kriteria keberhasilan, 70 dan $80 \%$, yaitu pada siklus II pertemuan 2 sebesar 83,33 untuk rata-rata kelas dan $85,71 \%$ untuk persentase penilaian. 


\section{DAFTAR PUSTAKA}

Arikunto, Suhardjono, \& Supardi. (2008). Penelitian tindakan kelas, Jakarta: Bumi Aksara.

Arikunto, Suharsimi. (2003). Prosedur penelitian. Jakarta: Bina Aksara.

BSNP. (2006). Kurikulum tingkat satuan pendidikan mata pelajaran IPS SD. Jakarta: BSNP.

Conny Semiawan, dkk. (1985). Media pembelajaran. Jakarta: Raja Grafindo Persada.

Depdikbud. (2003). Undang-Undang Nomor 20 Tahun 2003 tentang Sistem Pendidikan Nasional. Jakarta: Depdiknas.

Depdiknas. (2006). Kurikulum tingkat satuan pendidikan (ktsp). Jakarta: PB Dharma Bakti.

Djamarah, Syaiful Bahri. (2005). Strategi belajar mengajar. Jakarta: Rineka Cipta.

Mulyasa. (2002). Kurikulum berbasis kompetensi: konsep, karakteristik, dan implementasi. Bandung: Remaja Rosdakarya.

Poerwadarminta. (1978). Kamus umum bahasa Indonesia. Jakarta: Balai Pustaka.

Slavin, Robert E. (2008). Cooperative learning, teori, riset dan praktik. Terjemahan Nurulita. Bandung: Nusa Media.

Suhartato, dkk. (1994). Perencanaan pembelajaran. Bandung: Aksara.

Sukidin. (2003). Belajar dan pembelajaran. Bandung: Rineka Cipta.

Suryabrata, Sumadi. (2003). Metodologi penelitian. Jakarta: Raja Grafindo Persada.

Surdiman, A. M. (1992). Interaksi dan motivasi belajar mengajar. Jakarta: CV. Rajawali.

Syah, Muhibbin. (2008). Psikologi pendidikan. Bandung: Remaja Rosdakarya.

Wardani, I. G. A. K. dkk. (2007). Penelitian tindakan kelas Modul IDIK 4008. Jakarta: Universitas Terbuka. 